\title{
Species richness of arbuscular mycorrhizal fungi in forests with Araucaria in Southern Brazil
}

\author{
Roberta Boscaini Zandavalli ${ }^{1}$, Sidney Luiz Stürmer ${ }^{2}$ and Lúcia Rebello Dillenburg ${ }^{1,3}$
}

Received: 10.05.2007; accepted: 20.03.2008

\begin{abstract}
Species richness of arbuscular mycorrhizal fungi in forests with Araucaria in Southern Brazil). This study aimed to characterize species richness of arbuscular mycorrhizal fungi (AMF) in three distinct forests with Araucaria angustifolia (native forest, reforestation with A. angustifolia and plantation with Pinus taeda) in the "Floresta Nacional de São Francisco de Paula", State of Rio Grande do Sul, also accounting for seasonal variation. Six soil samples from each forest were collected from Araucaria angustifolia rhizosphere in four seasons during a one-year period, for identification of the AMF species. Spores were extracted by wet-sieving followed by centrifugation in water and $50 \%$ sucrose solution. The greatest richness (16 species) was found in the Araucaria reforestation and the lowest in the native forest (eight species). The season with higher species richness was different in each site. The most representative genera in all forests were Acaulospora and Glomus. Historical aspects and plant species composition can account for some of the differences among sites.
\end{abstract}

Key words: AMF, Araucaria angustifolia, Pinus taeda, reforestation

RESUMO - (Riqueza de espécies de fungos micorrízicos arbusculares em florestas com Araucaria no sul do Brasil). Este estudo teve como objetivo caracterizar a riqueza de espécies de fungos micorrízicos arbusculares (FMA) em três florestas distintas com Araucaria angustifolia (mata nativa, reflorestamento com A. angustifolia e plantação com Pinus taeda), em função da variação sazonal, na Floresta Nacional de São Francisco de Paula, Rio Grande do Sul. Seis amostras de solo foram coletadas da rizosfera de Araucaria angustifolia, em cada floresta, nas quatro estações, durante um ano, para identificação das espécies de FMA. Os esporos foram extraídos através de peneiramento úmido e centrifugação em água e solução de sacarose 50\%. A maior riqueza (16 espécies) foi encontrada na plantação de Araucaria e a menor na floresta nativa (oito espécies). Os gêneros que mais ocorreram foram Acaulospora e Glomus. A estação com maior riqueza de espécies foi diferente em cada local. Atribuiu-se ao histórico das áreas e à composição das espécies vegetais as diferenças encontradas entre os três locais de coleta.

Palavras-chave: Araucaria angustifolia, FMA, Pinus taeda, reflorestamento

\section{Introduction}

Araucaria angustifolia (Bert.) O. Ktze. (Araucariaceae) is one of the few gymnosperms in Brazil, and it occurs as an emergent tree component of the mixed ombrophyllous forests (Teixeira et al. 1986) or, simply, Araucaria forests. Its geographical distribution includes Argentina and Brazil, where it is concentrated in the southernmost States of Paraná, Santa Catarina and Rio Grande do Sul. It is long known that the species establishes a mutualistic association with arbuscular mycorrhizal fungi (AMF) (Milanez \& Monteiro 1950, Oliveira \& Ventura 1952), but few studies have been conducted in order to characterize the AMF species associated to the species under natural conditions. The first AMF survey in Araucaria rhizosphere was made on individuals growing in a botanical garden in São Paulo (Bononi et al. 1990), and 15 species were found. Ten years later, Breuninger et al. (2000) compared the richness of species between an area of Araucaria forest and an adjacent grassland in the northern highlands of Rio Grande do Sul, and found a two-fold difference in the number of species of AM fungi: 13 in the former and six in the latter. When comparing a native forest with Araucaria and a reforested area with both Araucaria and Pinus in the State of São Paulo, Moreira-Souza et al. (2003) found a greater number of AMF spores in the native forest (21 species) than

1. Universidade Federal do Rio Grande do Sul, Departamento de Botânica, Avenida Bento Gonçalves 9500, 91501-970 Porto Alegre, RS, Brazil

2. Universidade Regional de Blumenau, Departamento de Ciências Naturais, Caixa Postal 1507, 89010-971 Blumenau, SC, Brazil

3. Corresponding author: lucia.dillenburg@ufrgs.br 
in the reforested area (14 species). Recently, Moreira et al. (2007b) found $25 \mathrm{AMF}$ species three Araucaria ecosystems: a native forest (15 species), an Araucaria reforestation (13 species) and a burned Araucaria reforestation (13 species).

The slow growth rate of Araucaria angustifolia, its common association with AMF (e.g., Oliveira \& Ventura 1952, Muchovej et al. 1992, Breuninger et al. 2000, Moreira-Souza et al. 2003, Moreira et al. 2006), and its strong growth response to inoculation with AM fungi (Moreira-Souza \& Cardoso 2002, Zandavalli et al. 2004) suggest that the success of any plantation effort, aiming either the conservation or the sustainable use of the species, might greatly depend on ensuring that the young plants are colonized by the fungal partners.

In order to know which AMF species can be inoculated and to characterize the benefits of the fungus species to Araucaria angustifolia seedlings, we need to survey the AMF species that are associated with A. angustifolia in different locations. In this study, we aimed to briefly characterize species richness of arbuscular mycorrhizal fungi (AMF) associated to A. angustifolia in the "Floresta Nacional de São Francisco de Paula", State of Rio Grande do Sul, also accounting for the seasonal variation of such richness.

\section{Material and methods}

The study was conducted at a National Forest $\left(29^{\circ} 24^{\prime} \mathrm{S}\right.$ and $50^{\circ} 22^{\prime} \mathrm{W}, 912 \mathrm{~m}$ above sea level) located in the city of São Francisco de Paula, Rio
Grande do Sul, Brazil. The annual rainfall is around $2,469 \mathrm{~mm}$, and an annual dry season is not present (Mota et al. 1970). The mean temperature is about $14.5^{\circ} \mathrm{C}$, and the means of the highest and lowest temperatures are $20.3{ }^{\circ} \mathrm{C}$ and $9.9^{\circ} \mathrm{C}$, respectively. According to Fernandes \& Backes (1998), the soils in the region are Cambisols, characterized by fine texture, low $\mathrm{pH}$ and high levels of exchangeable $\mathrm{Al}$ and organic matter. A native forest and both an Araucaria and a Pinus plantation were chosen for this study. Selected soil characteristics for each specific site are shown in table 1 . The distance between any two sites varied between 2.5 and $3.0 \mathrm{~km}$. The Pinus taeda (Pinaceae) plantation is approximately 40 years old, and shows a pronounced occupation by several native tree species, including A. angustifolia and some species of Aquifoliaceae, Myrtaceae, Lauraceae, Podocarpaceae and Sapindaceae. The Araucaria reforestation is approximately 50 years old, with the upper canopy dominated by $A$. angustifolia and others species belonging to the Aquifoliaceae, Lauraceae, Myrsinaceae, Myrtaceae, Rutaceae and Sapindaceae. The upper canopy of the native forest is comprised by A. angustifolia and by other species of the same families found in the Araucaria reforestation.

Six soil samples were obtained from each of the three forest sites, in August and November 1999 and in February and May 2000. Each sample $(500 \mathrm{~g})$ consisted of four sub-samples, taken from the rizosphere of mature individuals of Araucaria, after litter removal, at a depth of 0-20 cm. Samples

Table 1. Chemical characteristics of the soil in the three forest sites at the "Floresta Nacional de São Francisco de Paula", Rio Grande do Sul, Brazil.

\begin{tabular}{lccc}
\hline & Pinus plantation & Araucaria reforestation & Native forest \\
\hline Clay $(\%)$ & 31.5 & 26.0 & 27.7 \\
$\mathrm{pH}($ in water) & 4.22 & 4.15 & 4.65 \\
Organic matter $(\%)$ & 6.57 & 6.05 & 5.32 \\
Cation exchange capacity $\left(\mathrm{cmol} \mathrm{l}^{-1}\right)$ & 22.9 & 22.5 & 19.6 \\
Base saturation $(\%)$ & 5.00 & 18.7 & 51.5 \\
$\mathrm{Al} \mathrm{saturation}(\%)$ & 33.9 & 22.8 & 5.35 \\
$\mathrm{Al}+\mathrm{H}\left(\mathrm{cmol} \mathrm{l}^{-1}\right)$ & 21.7 & 18.2 & 9.25 \\
$\mathrm{~N}(\%)$ & 0.18 & 0.17 & 0.15 \\
$\mathrm{P}\left(\mathrm{mg} \mathrm{l}^{-1}\right)$ & 3.62 & 2.90 & 2.35 \\
$\mathrm{~K}\left(\mathrm{mg} \mathrm{l}^{-1}\right)$ & 48.2 & 117 & 132 \\
$\mathrm{Al}\left(\mathrm{cmol} \mathrm{l}^{-1}\right)$ & 7.77 & 5.17 & 1.05 \\
$\mathrm{Ca}\left(\mathrm{cmol} \mathrm{l}^{-1}\right)$ & 0.55 & 2.97 & 7.50 \\
$\mathrm{Mg}\left(\mathrm{cmol} \mathrm{l}^{-1}\right)$ & 1.80 & 0.87 & 2.25 \\
\hline
\end{tabular}


were stored in polyethilene bags, under $4{ }^{\circ} \mathrm{C}$ temperature. All six samples from each site were pooled and homogenized. From this mix, $100 \mathrm{~g}$ soil sample was used to extract the spores. Spores were extracted by wet sieving (Gerdemann \& Nicolson 1963), followed by centrifugation in water and $50 \%$ sucrose solution (Jenkins 1964). The material were mounted on permanent slides using PVLG (polyvinyl alcohol, lactic acid, glycerol) and PVLG mixed with Melzer's reagent (iodine, chloral hydrate, potassium iodide and water), and identified by comparison to "vouchers" in slides. Active cultures and reference culture were obtained on INVAM (2000). The Jaccard index was used to evaluate species similarity between sites, and was calculated as $c /(a+b-c)$, where $a$ and $b$ are the species richness of each of the two sites being compared and $c$ is the number of species they have in common.

\section{Results and Discussion}

The AMF species identified in each forest and season are listed in table 2 . The native forest had the lowest overall species richness, with only eight AMF taxa recorded: four Acaulospora and four Glomus species. Nine taxa were found in the Pinus plantation, distributed into three genera: six Acaulospora, two Scutellospora and one Glomus. The highest number of species and genera was found in the Araucaria reforestation, with 16 taxa, distributed into five genera: eight Acaulospora, three Glomus, three Scutellospora, one Entrophospora and one Gigaspora. While both the Pinus plantation and the Araucaria reforestation had several species which were detected in all seasons, only Glomus sinuosum was identified in all seasons in the native forest.

Table 2. Arbuscular mycorrhiza fungal (AMF) taxa found in three forest sites at the "Floresta Nacional de São Francisco de Paula", RS, Brazil. Seasons: $\mathrm{Sp}=$ spring, $\mathrm{Su}=$ summer, $\mathrm{Fa}=$ fall and $\mathrm{Wi}=$ winter.

\begin{tabular}{|c|c|c|c|c|c|c|c|c|c|c|c|c|}
\hline \multirow{2}{*}{ AMF taxa } & \multicolumn{4}{|c|}{ Araucaria reforestation } & \multicolumn{4}{|c|}{ Pinus plantation } & \multicolumn{4}{|c|}{ Native forest } \\
\hline & $\mathrm{Sp}$ & $\mathrm{Su}$ & $\mathrm{Fa}$ & Wi & $\mathrm{Sp}$ & $\mathrm{Su}$ & $\mathrm{Fa}$ & Wi & $\mathrm{Sp}$ & $\mathrm{Su}$ & $\mathrm{Fa}$ & Wi \\
\hline Acaulospora bireticulata Rothwell \& Trappe & & $\mathrm{X}$ & & & & & & $\mathrm{X}$ & & & & \\
\hline Acaulospora foveata Trappe \& Janos & & $\mathrm{X}$ & & $\mathrm{X}$ & $X$ & & $\mathrm{X}$ & $\mathrm{X}$ & & & & \\
\hline Acaulospora koskei Błaszk & & & & & $\mathrm{X}$ & $\mathrm{X}$ & $\mathrm{X}$ & $\mathrm{X}$ & & & & \\
\hline Acaulospora lacunosa Morton & & $\mathrm{X}$ & $\mathrm{X}$ & & $\mathrm{X}$ & $\mathrm{X}$ & $\mathrm{X}$ & $\mathrm{X}$ & & & & \\
\hline Acaulospora mellea Spain \& Schenck & $\mathrm{X}$ & $\mathrm{X}$ & $\mathrm{X}$ & $\mathrm{X}$ & $\mathrm{X}$ & $\mathrm{X}$ & $\mathrm{X}$ & $\mathrm{X}$ & & & $\mathrm{X}$ & $\mathrm{X}$ \\
\hline Acaulospora scrobiculata Trappe & $\mathrm{X}$ & $\mathrm{X}$ & $\mathrm{X}$ & $\mathrm{X}$ & & & & & & $\mathrm{X}$ & $\mathrm{X}$ & \\
\hline Acaulospora spinosa Walker \&Trappe & $\mathrm{X}$ & $\mathrm{X}$ & $\mathrm{X}$ & $\mathrm{X}$ & & & & & & & & \\
\hline Acaulospora tuberculata Janos \& Trappe & & $\mathrm{X}$ & $\mathrm{X}$ & & & & & & & & $\mathrm{X}$ & $\mathrm{X}$ \\
\hline Acaulospora sp. 1 & & & & & & & & & & & & $\mathrm{X}$ \\
\hline Acaulospora sp.2 & & $\mathrm{X}$ & & & & & & & & & & \\
\hline Acaulospora sp. 3 & & & & & $\mathrm{X}$ & & & & & & & \\
\hline Entrophospora infrequens (Hall) Ames \& Schneider & $\mathrm{X}$ & & & & & & & & & & & \\
\hline Gigaspora decipiens Hall \& Abbott & & $\mathrm{X}$ & & & & & & & & & & \\
\hline Glomus ambisporum Smith \& Schenck & $\mathrm{X}$ & $\mathrm{X}$ & $\mathrm{X}$ & $\mathrm{X}$ & & & & & & $\mathrm{X}$ & $\mathrm{X}$ & $\mathrm{X}$ \\
\hline Glomus clarum Nicolson \& Shenck & & & & & & & & & & $\mathrm{X}$ & & \\
\hline Glomus pansihalos Berch \& Koske & & & & & & & & & & $\mathrm{X}$ & & \\
\hline Glomus sinuosum (Gerd. \& Bakshi) Almeida \& Schenck & $\mathrm{X}$ & $\mathrm{X}$ & $\mathrm{X}$ & $\mathrm{X}$ & $\mathrm{X}$ & & $\mathrm{X}$ & $\mathrm{X}$ & $\mathrm{X}$ & $\mathrm{X}$ & $\mathrm{X}$ & $\mathrm{X}$ \\
\hline Glomus sp. 1 & $\mathrm{X}$ & & & & & & & & & & & \\
\hline Scutellospora fulgida Koske \& Walker & & $\mathrm{X}$ & & & & & & & & & & \\
\hline Scutellospora pellucida (Nicolson \& Shenck) Walker \& Sanders & & & & $\mathrm{X}$ & & & & & & & & \\
\hline Scutelospora verrucosa (Koske \& Walker) Walker \& Sanders & & & & $\mathrm{X}$ & & & & & & & & \\
\hline Scutellospora sp.1 & & & & & $\mathrm{X}$ & & & & & & & \\
\hline Scutellospora sp.2 & & & & & $\mathrm{X}$ & & & & & & & \\
\hline
\end{tabular}


In mature, undisturbed forests, spores may be relatively less important than other vegetative propagules, and the colonization of new roots is achieved primarily by the soil hyphal networks (Jasper et al. 1989). As a result, native forests, which are older and less productive than younger forests, usually have small spore populations and high mycorrhizal colonization levels (Muthukumar et al. 2003). The native forest surveyed in this study is older and probably less productive than both the plantation and the reforestation, and apparently with lowest regeneration of tree species in general, which could explain the low number of AMF taxa.

Spore number in the native forest (16.49 spores.g-1) was also low when compared to the Araucaria reforestation (40.12 spores g-1), but similar the Pinus plantation (13.74 spores g-1). Although these data might be overestimated, due to the possible inclusion of non-infective and dead spores in the count, the comparison among sites is still valid. In contrast to Moreira-Souza et al. (2003) and Moreira et al. (2007a), but in agreement with Moreira et al. (2006), we found greater spore abundance in the Araucaria reforestation than in the native forest. These contrasting observations are probably related to historical and structural differences between the examined forests.

Previous studies by Duarte et al. (2002) have reported a significantly higher growth rate of Araucaria angustifolia seedlings in the same Pinus plantation and Araucaria reforestation surveyed in the present study. Also, daily mean values of irradiance were higher in the Pinus plantation than in the other two sites, suggesting a greater productivity in this forest plantation, compared to the other two forests. It is important to point out that, despite the favorable environment offered by the Pinus plantation to the recruitment and growth of young individuals of $A$. angustifolia, this forest site has its overstory dominated by Pinus taeda, a characteristically ectomycorrhizal species (Hacskaylo \& Vozzo 1971), which may explain the much lower count of AMF spores in this site, compared to the reforestation with A. angustifolia.

The Araucaria reforestation was the only site where the genera Entrophospora and Gigaspora were represented in the soil samples. Also, the taxa Acaulospora sp. 2, A. spinosa, Glomus sp. 1, Scutellospora fulgida, S. pellucida and S. verrucosa were exclusively recorded in this site. The variety of native plant species and the relative young age of the Araucaria reforestation might be related to its high number of AMF species. According to Mosse \& Bowen (1968) and Muthukumar et al. (2003), a continuous root grow is associated with a large potential of sporulation.

Acaulospora and Glomus accounted for the majority of the taxa associated with the rhizophere of Araucaria angustifolia, and were the only two genera sampled in the native forest. On the other extreme, Gigaspora spores were poorly represented in all three sites. The soils of the region are acidic (table 1) and, according to Stürmer (1999), Acaulospora species are frequently found in such soils, while Gigaspora is associated to alkaline ones (Melo et al. 1997). The genera Acaulospora and Scutellospora were more abundantly represented in the two sites with the lowest $\mathrm{pH}$, i.e. Araucaria reforestation and Pinus plantation. Glomus, on the other hand, was represented by a larger number of species in the site with the highest $\mathrm{pH}$, i.e. the native forest. The greatest overall fertility (table 1) of the native forest probably generated a weaker stimulus to host plant mycorrhizal colonization and, consequently, lower spore abundance and reduced number of taxa. Considering that $\mathrm{P}$ availability was low in all three sites, it does not seem that the availability of this specific nutrient is governing the observed differences. One must have in mind, however, that correlating soil characteristics to AMF occurrence is not an easy task, because several other variables may influence fungal sporulation.

The number (23) and identity of the taxa reported in the present study were similar to those of previous surveys of AMF species associated with Araucaria angustifolia (Bononi et al. 1990, Breuninger et al. 2000, Moreira-Souza et al. 2003). Recently, Moreira et al. (2007b) found a total of 25 taxa in a survey of three A. angustifolia ecosystems in the State of São Paulo. Also, in all the before-mentioned studies, Acaulospora and Glomus were the genera with the greatest number of species.

The Jaccard index of similarity between the native forest and the Araucaria reforestation was 0.20 , while the value between these two forests compared to the Pinus plantation was lower (0.14 in both cases). This is not surprising, due to the similarity in plant species composition between the two Araucaria forests (native forest and Araucaria reforestation). Although sharing some of the tree species with the other two forests (though most of them in the seedling stage), the Pinus plantation, as 
already said, is dominated by an ectomycorrhizal tree species, Pinus taeda.

The season of the year with the greatest number of taxa varied among areas (table 2): summer for the Araucaria reforestation (12 taxa), spring for the Pinus plantation (eigh taxa), and summer, fall and winter for the native forest (five taxa). Glomus sinuosum was absent only in one season (summer) in the Pinus plantation site, and Acaulospora mellea just in the spring and summer in the native forest. These two species seem to be the most generalist ones. The fact that some AMF species were found only in a specific season may be due to the fact that different AMF have different sporulation times, a response which has been interpreted as a strategy to reduce direct competition (Gemma et al. 1989). The number of taxa found in a site also depends on sample size. In some of the sites and/or seasons, the number of taxa may have been underestimated, due to the assincronic and clumped sporulation of the species (Gemma et al. 1989, Friese $\&$ Koske 1991). The seasonal sampling was then of particular importance to reach for a more complete survey of the AMF species.

\section{Acknowledgements}

The authors thank the staff of the "Floresta Nacional de São Francisco de Paula" for allowing the execution of this study and for technical assistance, and the "Conselho Nacional de Desenvolvimento Científico e Tecnológico" (CNPq), for the graduate and research fellowships granted to the first and last author, respectively.

\section{Literature cited}

Breuninger, M., Einig, W., Magel, E., Cardoso, E. \& Hampp, R. 2000. Mycorrhiza of Brazil Pine (Araucaria angustifolia [Bert. O. Ktze.]). Plant Biology 2: 4-10.

Bononi, V.L.R., Grandi, R.A.P., Lopes, S.A.R.L., Rodrigues, E. \& Fonseca, M.P. 1990. Micorrizas vesiculo-arbusculares em Araucaria angustifolia (Bertoloni) O. Kuntze. Revista do Instituto Florestal 2: 87-93.

Duarte, L., Dillenburg, L.R. \& Rosa, L.M.G. 2002. Assessing the role of light availability in the regeneration of Araucaria angustifolia (Araucariaceae). Australian Journal of Botany 50: 741-751.

Fernandes, A.V. \& Backes, A. 1998. Produtividade primária em floresta com Araucaria angustifolia no Rio Grande do Sul. Iheringia, série Botânica 51: 63-78.
Friese, C.F. \& Koske, R.E. 1991. The spatial dispersion of spores of vesicular-arbuscular fungi in a sand dune: microscale patterns associated with the root architecture of American beachgrass. Mycological Research 95: 952-957.

Gemma, J.N., Koske, R.E. \& Carreiro, M. 1989. Seasonal dynamics of selected species of VA mycorrhizal fungi in a sand dune. Mycological Research 92: 317-321.

Gerdemann, J.W. \& Nicolson, T.H. 1963. Spores of mycorrhizal Endogone species extracted from soil by wet sieving and decanting. Transactions of the British Mycological Society 46: 235-244.

Hacskaylo, E. \& Vozzo, J.A. 1971. Inoculation of Pinus caribaea with ectomycorrhizal fungi in Puerto Rico. Forest Science 17: 139-245.

Invam. 2000. International culture collection of (vesicular) arbuscular mycorrhizal fungi. http://invam. caf.wvu.edu/fungi/taxonomy/speciesID.htm (acesso em 07.2000).

Jasper, D.A., Abbot, L.K. \& Robson, A.D. 1989. Soil disturbance reduces the infectivity of external hyphae of VA mycorrhizal fungi. New Phytologist 112: 93-99.

Jenkins, W.R. 1964. A rapid centrifugal-flotation technique for separating nematodes from soil. Plant Disease Reporter 48: 692.

Melo, A.M.Y., Maia, L.C. \& Morgado, L.B. 1997. Fungos micorrízicos arbusculares em bananeiras cultivadas no vale do submédio São Francisco. Acta Botanica Brasilica 11: 115-121.

Milanez, F.R. \& Monteiro, N.H. 1950. Nota prévia sobre a micorriza do pinho do Paraná. Arquivos do Serviço Florestal 4: 93-97.

Moreira, M., Baretta, D., Tsai S.M. \& Cardoso, E.J.B.N. 2006. Spore density and root colonization by arbuscular mycorrhizal fungi in preserved or disturbed Araucaria angustifolia (Bert.) O. Ktze. ecosystems. Scientia Agricola 63: 380-385.

Moreira, M., Baretta, D., Tsai S.M. Gomes-da-Costa, S.M. \& Cardoso, E.J.B.N. 2007a. Biodiversity and distribution of arbuscular mycorrhizal fungi in Araucaria angustifolia (Bert.) O. Ktze. forest ecosystems. Scientia Agricola 64: 393-399.

Moreira, M., Nogueira, M.A., Tsai S.M., Gomes-daCosta SM \& Cardoso, E.J.B.N. 2007b. Sporulation and diversity of arbuscular mycorrhizal fungi associated with Brazil Pine in the field and in the greenhouse. Mycorrhiza 17: 519-526.

Moreira-Souza, M. \& Cardoso, E.J.B.N. 2002. Dependência micorrízica de Araucaria angustifolia (Bert.) O. Ktze. sob doses de fósforo. Revista Brasileira de Ciência do Solo 26: 905-912.

Moreira-Souza, M., Trufem, S.F.B., Gomes-daCosta, S.M. \& Cardoso, E.J.B.N. 2003. Arbuscular 
mycorrhizal fungi associated with Araucaria angustifolia (Bert.) O. Ktze. Mycorrhiza 13: 211-215.

Mosse, B. \& Bowen, G.D. 1968. The distribution of Endogone spores in some Australian and New Zealand soils in an experimental field soil at Rothamsted. Transactions of the British Mycological Society 51: 485-492.

Mota, F.S., Goedert, C.O., Lopes, N.F., Gardez, J.R.B. \& Gomes, A.S. 1970. Balanço hídrico do Rio Grande do Sul. Pesquisa Agropecuária Brasileira 5: 1-27.

Muchovej, R.M.C., Alves, A.C., Muchovej, J.J. \& Kasuya, M.C.M. 1992. Influência da inoculação com fungos ectomicorrízicos e MVA sobre o comportamento de mudas de Araucaria angustifolia (Bert.) O. Ktze. Hoehnea 19: 9-18.

Muthukumar, T., Sha, L., Yang, X., Cao, M., Tang, J. \& Zheng, Z. 2003. Distribution of roots and arbuscular mycorrhizal associations in tropical forests types of Xishuangbanna, southwest China. Applied Soil Ecology 22: 241-253.

Oliveira, M. \& Ventura, A. 1952. Ocorrência de micorriza em Araucaria angustifolia (Bert.) O. Ktze. e Podocarpus lamberti Kl. ed. 25. Serviço Florestal, São Paulo.

Teixeira, M.B., Coura-Neto, A.B., Pastore, U. \& Rangel Filho, A.L.R. 1986. Vegetação; as regiões fitoecológicas, sua natureza, seus recursos econômicos; estudo fitogeográfico. In: Levantamento de recursos naturais. IBGE, Rio de Janeiro, v. 33, pp. 541-632.

Stürmer, S.L. 1999. Evolução, classificação e filogenia dos fungos micorrízicos arbusculares. In: J.O. Siqueira, F.M.S. Moreira, A.S. Lopes, L.R.G. Guilherme, V. Faquin, A.E. Furtini Neto \& J.G. Carvalho (eds.). Inter-relação fertilidade, biologia do solo e nutrição de plantas. Sociedade Brasileira de Ciência do Solo, Lavras, pp. 797-817.

Zandavalli, R.B., Dillenburg, L.R. \& Souza, P.V.D. 2004. Growth responses of Araucaria angustifolia (Araucariaceae) to inoculation with mycorrhizal fungus Glomus clarum. Applied Soil Ecology 25: 245-255.Table 1. Chemical characteristics of the soil in the three forest sites at the "Floresta Nacional de São Francisco de Paula", Rio Grande do Sul, Brazil. 